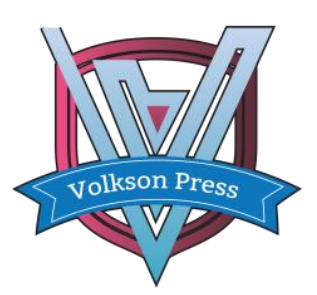

Contents List available at VOLKSON PRESS

Economics \& Management Innovations(EMI)

DOI : http://doi.org/10.26480/icemi.01.2017.77.79

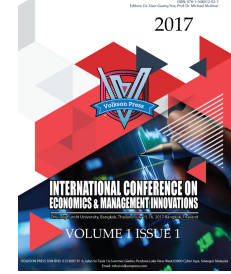

\title{
Analysis of the Uniform Legislation of Commercial Registration under the Background of Compilation of the "Civil Code"
}

\section{Jingmin Shi ${ }^{*}$ Liqin Zhang}

Wuhan University of Technology, Hongshan District, LuoShi South Road, No. 205 Wuhan City, Hubei Province, China.

*1332021197@qq.com

This is an open access article distributed under the Creative Commons Attribution License, which permits unrestricted use, distribution, and reproduction in any medium, provided the original work is properly cited.

\section{ARTICLE DETAILS}

\section{Article History:}

Received 02 october 2017 Accepted 06 october 2017 Available online 11 october 2017

\section{Keywords:}

commercial registration; reform; unified legislation;

\section{ABSTRACT}

Based on the reform of the commercial registration system and the compilation of the Civil Code and the promulgation of the "General Principles of Civil Law", this paper discusses the necessity and feasibility of the unified legislation of the commercial registration system under the background of deepening the reform of the economic system in our country. Then there is a brief discussion on the Model of Uniform Legislation of Commercial Registration System in China.

\section{Background of the Double Reform}

On March 15, 2017, the National People's Congress passed the resolution on the "General Principles of the Civil Code of the People's Republic "of China, it is the first step in the success of the Chinese Civil Code. At the same time, the reform of China's commercial registration system is also drastically carried out.

Reform of the Local commercial registration system began in 2012, so far, Guangdong, Fujian Province, Shanghai Free Trade Zone has completed the reform on the local commercial registration system pilot: Guangdong Provincial People's Congress Standing Committee issued a "Business registration regulations in guangdong province" on December 3, 2015. The Fujian Provincial People's Government has promulgated the "Fujian Province to investigate and deal with undocumented operating practices," " Fujian industrial and commercial registration system reform follow-up market supervision work program "and a series of local regulations on the basis of the pilot in Pingxi, Xiamen, Fuzhou ; Shanghai Trade and Industry Bureau issued a State Administration for Industry and Commerce to support a number of views of the Shanghai Free Trade Area, and in 2016 In January 2017, the State Council to further deepen the reform of the commercial registration system, issued a "thirteen five" market supervision plan ", the implementation of the business registration system reform to achieve the reform of the business registration system, "From point to surface" to promote market reform and innovation. ${ }^{[i]}$ China's the market regulation on the commercial registration behavior has achieved the regional pilot and the national reform and innovation. On the background of the compilation of the "Civil Code", civil and commercial law scholars have begun to think, the possibility of a unified commercial registration legislation.

\section{2. necessity of Unified Legislation of Commercial Registration}

China's commercial registration of legal norms scattered and content is complex,China has established a commercial registration legal system in line with the economic reform, the basic principles can not fully adapt to China's modern socialist market economy development.To promote the renewal of China's commercial registration theory system, to meet the needs of China's market economy development, it is the guarantee of China's legal reform to develop a unified business registration law, and the reform of the local commercial registration system has been basically completed, it is time to issue a commercial registration unified legislation. In the case of commercial subject, commercial subject plays a decisive role in the commercial registration system of our country, but it has no definite definition in the existing commercial legal norms of our country. The commercial subject is divided into different forms of its ownership, to a certain extent, caused the commercial subject of unequal market position. In the local commercial registration system reform pilot, "Guangdong Province Commercial Registration Ordinance" in its second paragraph 3 of the extension of the main commercial extension, but also does not specify the basic concept of commercial subjects. [ii]

China's current commercial registration of legal norms, the overall public color is more intense, especially in the market access, through the analysis of the pilot reform in recent years, the results of the relaxation of access standards, the implementation of "wide into the strict control" to strengthen the matter, After the supervision has become China's trend of the reform of the commercial registration system . In December 2014, Premier Li Keqiang clearly pointed out at the executive meeting of the State Council: "We want to build a unified national market," and to build a unified national market, legislators must develop a consistent business registration system to the elimination of local protectionism and market access discrimination, to achieve the commercial subject in the country within the equality. [iii] In recent years, many countries and regions maintain the status of the equality of the commercial subject through the commercial legislation, our legislators should also conform to the core concept of modern market economy, achieving the fair and fair business registration.

\section{Feasibility of a Unified Legislation on Commercial Registration}

\section{1 extraterritorial experience}

The system of commercial registration in the modern sense of the world is appeared in Germany, which in 1869 promulgated the "Ordinary German Commercial Code" and the German Commercial Code of 1897, which systematically stipulated the commercial registration system, "German Commercial Code "In the second chapter of part1 the business register is stipulated, and there are supplements in other sections of the business registration .The provisions of the German Commercial Code have a very important guiding role on the other civil law countries, Most of the civil law countries have a unified provision on the commercial or general business registration.For example, Japan in the Meiji Restoration period had learned, transplant, following the German commercial law system,established a mature business system, Japan promulgated "Commercial Code"in 1899, there are provisions of the commercial registration in its first general provisions, and in 1963 promulgated the "Business Registration Law", "Business Registration Rules", in 2005 
promulgated the "Company Law", clearing Company registration related matters. ${ }^{[i v]}$ China's legal system is a self-contained system of socialism with Chinese characteristics, but it also draws on the substantive law of civil law system, the idea of the prosecution and defense of Anglo-American law system and the essence of Chinese legal system. In fact, as early as 1999, Chinese scholars began to discuss the possibility of unified legislation of China's commercial registration system. For the coordination and reunification of China's commercial registration system, China's commercial registration system has the necessity of unified legislation, there are many experiences of the domain to learn from.

\section{2 theoretical support of the unified legislation of commercial registration}

Since 2005, Chinese scholars have made great efforts to discuss the possibility and feasibility of the legislation of China's commercial registration and began to provide the path design of the unified legislation of commercial registration in China. The academic circles have carried on the thorough discussion and the research to our country's commercial law system. And as early as the Ninth National People's Congress, the NPC has put forward the "Commercial Registration Law" legislative proposals. In fact, in the process of compilation of the "Civil Code" , civil law and commercial law should reach a basic consensus model to deal with civil law and commercial legislation, that is, for civil law, , "Civil Code"should contain the commercial law common rules, and issue separated legislation for special rules of commercial law . [v] In view of the system of unified registration of listed companies, Dr. Liu put forward a set of complete system construction idea, the market entry mechanism of information registration, information publicity and credit supervision mechanism, relief mechanism and responsibility system, the market launch mechanism to start the discussion, provided an important reference for China's commercial registration law Construction.

\subsection{The practice of commercial registration reform}

In recent years, China's administrative regulations, local regulations provides the commercial registration of legal norms of legislation a legislative practice experience. In February 2014, the State Council clearly "actively promote the unified commercial registration legislation in "registered capital registration system reform program", 1 the commercial registration legislation issued by the local governments all used Commercial registration unified legislative model in Zhuhai, Shenzhen, Xiamen, Guangzhou and other provinces and cities, Guangdong Province is more in the forefront of reform - promulgated the local regulations "Guangdong Province Commercial Registration Ordinance", these local reform provides practical experience for the reunification of China's commercial registration legislation .

\section{Explore to Legislative Model of Commercial Registration}

\subsection{Civil and Commercial Unity: be included in "Civil Code"}

The compilation of China's "civil code" has started the first step, as the development of China 's "one way along the way" strategy, China's socialist market economy began to release a huge amount of energy, however China's existing commercial registration system is clearly unable to adapt to China's economy, Is it possible to develop a "business rule" + a special business law to harmonize commercial relations as in the previous General Principles of Civil Law? The discussion to China's civil and commercial integration and civil and commercial separation has been going on for many years,In the drafting of the General Principles of Civil Law, some scholars suggested to make clear the positioning of commercial subjects in the General Principles of Civil Law,But on the view of the "Civil Law General" ,which adopted by the National People's Congress, the main changes in the provisions of the main body of the legal entity is that the main body of the legal entity is divided into profit-making legal person, non-profit legal person, "special legal person"based on whether it is for profit.The principle of compiling the General Principles of Civil Law is adhere to the principle of "big private law" : focus on the "common law" of the "sub-rules" to define the basic rules of civil law . [vi]Article 77 of the "General Principles of Civil Law "stipulates that only the "profit-making legal person shall be registered in accordance with the law" shall be set forth in the "Law of the People's Republic of China".The legislative principles of the General Principles of Civil Law leave a huge space for the follow-up legislation. The Civil Code can take a "civil and commercial" approach without prejudice to the appropriateness of its internal logic. Independent of the possibility of compiling, but the commercial registration norms are clearly with the "public law color", which should not be included in the "civil code" system.

\section{2 the development of "business rules"}

Over the years, China's commercial law scholars to highlight the importance of the main business and independence, has always advocated the development of "business rules" of the legislative model,that is "Commercial General" provides "businessmen, business behavior, commercial dispute resolution", business special law :Securities law, Company law, Insurance law, etc. to continue to maintain forms of single legislation. [vii] China's commercial law scholars have specifically designed the system and structure of "business rules"referred to the "General Principles of Civil Law", "Commercial General" are designed for 10 chapters, including one independent chapter with provisions of commercial registration, includes the business registration authority, registration scope, registration procedures. There are other scholars think that "General Business" should be divided into three parts, General, Merchant and Merchant Behavior, according to this model, the provisions of commercial registration will be scattered in the chapter, However, the legislative process is always long, there are still controversies in the academic theory of China's basic theory, and in the compilation of the Civil Code, commercial norms are likely to be absorbed by the Civil Code, it is long way to go that unifying the commercial registration system through the introduction of "General Business" . [viii]

\section{3 enactment of the "Commercial Registration Act"}

According to the reform trend of China's current business registration system,it is the most feasible to develop a unified "Commercial Registration Law" , and it has the following three advantages: Achieve the consistency of Jurisprudence Idea of Commercial Registration System. Uniform legislation can improve the current situation of complexity law ,clear the legal blind spot, reduce the cost to maintenance of legal coordination ; Enhance the level of China's commercial registration legislation. the development of "Commercial Registration Law" can solve the problem that current low level of commercial registration legislation the effect is weakened, clear the effectiveness of the commercial registration system and achieve the purpose of commercial registration. A unified legislative model can promote the spirit of freedom, equality and fairness at the source of law.For example, the model of the reform of the commercial registration system - the Guangdong Provincial People's Congress has passed and promulgated the "Guangdong Province Commercial Registration Ordinance", its legislative structure contains the general rules, registration matters, filing matters, registration procedures, information publicity and credit constraints, legal responsibility and The Supplementary Provisions provide an important reference for the unified legislation of commercial registration in China.

In the new commercial registration legal system, the government should serve as an auxiliary role. The "Decision" ${ }^{2}$ adopted by the Third Plenary Session of the Eighteenth Central Committee put forward "to make the market play a decisive role in the allocation of resources and the government play a better role in the economic market". It is clear that China's market economy system is characterized by "limited market and surplus government" to the "limited government, the rest of the market" model of the structure of the flip, so the relationship between government and market should be properly handled in the principles and concepts in the "Commercial Registration Law", establish the role of government and market in the Commercial Registration Law according to the needs of the socialist market economic system, the concept, principle and operation mechanism of the commercial registration law. Business registration authority should achieve the functional transformation: the government in the "identification function" from the supervision to the service, "selection function" from the leading to the auxiliary function, "regulatory function" from control to governance, "control function" from direct to indirect. ${ }^{[\mathrm{ix}]}$

\section{Conclusions}

The benefit of the reform of the commercial registration system is being released. The system of commercial registration is expressed in a unified form, not only in the form of formal dimension, but also in the substantive level, that is, to further stimulate the reform results at the legislative level. In fact, "system integration" can achieve the goal of optimizing the commercial registration system structure, eliminating the conflict between commercial registration norms, making up the loopholes in the system. Now we need to think about the model of the unified commercial registration legislation, which can achieve not only the function of the main business services, but also a reasonable constraint on commercial 
registration behavior.

\section{References}

[1] Information on http: //www.gov.cn/zhengce/content/201701/23/content_5162572.htm, visit time : May 15, 2017.

[2] Information on http://gongwen.cnrencai.com/tiaoli/32956.html, visit time : May 17, 2017.

[3] XunzhiLiu ,Commercial registration unified legislation[M], China University of Political Science and Law Press, 2015 edition, p.61.

[4] Fan Chun, Hansheng Wen ,highlight the efficiency: the reform of the Japanese business registration system[M], Journal of Heilongjiang Administrative Cadre Institute of Politics and Law, 2005, 03.
[5] Jian Fan, Wang Jianwen, the value of business law, source and ontology (second edition)[M], China Renmin University Press, 2007 edition, p. 385.

[6] Haijing Xiao,The Path Choice of Commercial Subject 's Legislative Orientation in the Compilation of Civil Code[J],Chinese law,2016,04:55-72.

[7] Xia Xiong, The expression of "codification" of commercial norms in the context of the codification of civil code [J]. Law 2016, 12: 41-49.

[8] Yunsheng Liu.Technology of Commercial General Theory [J] . Hebei Law Science, 2007,04: 106-114.

[9] Su Chen,Communication of government and market in commercial law mechanism [J]. Chinese Journal of Law, 2014,05: 41-59. 